\section{How to increase demand for carp? Consumer attitudes and preferences in Germany and Poland}

How to increase demand for carp?

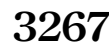

Katrin Zander

\author{
Thuenen Institute of Market Analysis, Braunschweig, Germany, and \\ Yvonne Feucht \\ Independent Researcher, Hamburg, Germany
}

Received 26 November 2019

\begin{abstract}
Purpose - Carp is a traditional aquaculture fish with decreasing relevance in European markets. Despite this, it is a protein source which could contribute to the worldwide protein supply. Traditional carp ponds are part of human cultural heritage with high relevance for biodiversity. But, market shares of carp are small compared to other seafood market, mainly due to low consumer demand. The aim of this research was to contribute to the discussion on how to increase demand for carp by testing the acceptance of selected preprocessed carp products.

Design/methodology/approach - A quantitative online survey was conducted in Germany and Poland with the aim of identifying consumers' attitudes towards carp and carp products. On this basis recommendations on how to best market carp products are developed.

Findings - Carp is perceived to be a fish eaten primarily at Christmas and New Year's Eve and to be difficult to prepare. The analyses reveal that a potential for novel carp products does exist in Germany and in Poland. The wider introduction of a bonecut filet to the market, a better availability of carp products, and the avoidance of off-flavors are important prerequisites for higher market relevance of carp.

Research limitations/implications - In this research consumer preferences were elicited "theoretically" by showing pictures of carp products and asking them for their preferences. In this regard, the results presented here state a general consumer interest and a potential for new carp products. Further research, integrating product tastings might give additional information on the likely success of new types of carp products.

Practical implications - In order to let people know about the new products and at the same time to combat the sometimes existent bad image of carp, product tastings, also in combination with information regarding local origin and environmental/cultural impact, should be offered at the point of sale.

Originality/value - Carp is a highly sustainable fish and offers a valuable protein source for human consumption. But, in its common ways of market presentation it is not highly appreciated by consumers. This paper demonstrates options of overcoming this situation.
\end{abstract}

Keywords Consumer research, Sustainable food, Fish, Aquaculture

Paper type Research paper

\section{Introduction}

Fish accounts for about $17 \%$ of the animal products consumed worldwide and plays an important role for global food security and protein supply (FAO, 2018; Richter and Klöckner,

C Katrin Zander and Yvonne Feucht. Published in British Food Journal. Published by Emerald Publishing Limited. This article is published under the Creative Commons Attribution (CCBY 4.0) licence. Anyone may reproduce, distribute, translate and create derivative works of this article (for both commercial and noncommercial purposes), subject to full attribution to the original publication and authors. The full terms of this licence may be seen at: http://creativecommons.org/licences/by/4.0/legalcode

We acknowledge the funding of this research as part of the SUCCESS project by the European Union's Horizon 2020 research and innovation program under grant agreement No 635188. 
$\mathrm{BFJ}$

122,11

3268

2017). Whereas in earlier times seafood originated mainly from catching wild fish, aquaculture has become more and more important in recent times. In 2016, it accounted for half of worldwide seafood production (FAO, 2018). Aquaculture's share in the annual turnover from first sale value was nearly two-thirds (FAO, 2018). Aquaculture has become an important global protein source and one which has a lower environmental impact than ruminant meat production (Clark and Tilman, 2017).

In its beginnings aquaculture was seen as an option to reduce overfishing and to mitigate negative environmental impacts of fishing. However, aquaculture itself can create ecological problems as well as health risks for consumers, this is partly due to the fact that it has intensified over time (Teufel, 2004; FAO/NACA, 2010; Jacobs et al.,2002; Olesen et al.,2011). Public awareness of these risks and problems affects acceptance of aquaculture and its products (Bergleiter and Meisch, 2015). Several studies indicate that consumers in various countries are concerned about sustainability and animal welfare in fish farming or aquaculture (e.g. Altintzoglou et al., 2010; Carlucci et al., 2015; Feucht and Zander, 2015; Kalshoven and Meijboom, 2013; Olesen et al., 2010; Verbeke et al., 2007; Whitmarsh and Palmieri, 2011; Zander and Feucht, 2018). For example, a German study revealed that consumers were particularly interested in the reduction of environmental pollution, in animal welfare issues, in near-natural production and - this is related to health considerations - minimal use of drugs in sustainable aquaculture (Risius et al., 2017).

There are several ways to address these societal and consumer concerns in modern aquaculture: (1) starting to modify aquaculture production systems to reduce their environmental impacts and to improve fish welfare and/or (2) utilize fish species which are per se more environmentally friendly in their production. An example for fish which fits into the latter category is carp. Carp farming is an old tradition in central Europe and takes place in pond systems. It is a very environmentally friendly fish farming system (Mergili, 2009; Teufel et al., 2004). In contrast to, e.g. trout, carp feeds on microorganisms and plants which naturally occur in ponds. Production intensity can be increased by feeding cereals, but it is not necessary to feed animal proteins (Mergili, 2009; Teufel et al., 2004).

Earlier research, also from Germany, has shown that ponds, commonly used for carp farming, are the aquaculture system most readily accepted by consumers, and that this system is in line with their expectations of sustainable fish farming (Feucht and Zander, 2015). In this respect, carp production presumably exactly corresponds to consumers' expectations regarding sustainable production. In times of increasing importance of sustainability issues in consumers' purchase decision, the eco-friendliness of carp might provide additional market potential.

But the demand for carp is low and the market share of common carp is less than $1 \%$ in Germany (FIZ, 2018). The reasons might be that carp, although rather well-known, is frequently not perceived as being tasty, of questionable quality and inconvenient in size (Feucht and Zander, 2015). Also, findings from France show that carp is not very highly appreciated by consumers and perceived as having a questionable image (Vallod, 1995), and Austrian consumers describe carp as a fatty fish (Bauer and Schlott, 2009). Qualitative research from Germany and Poland highlights that consumers depict carp as a seasonal product, mainly for Christmas and New Year's Eve, and as a local specialty with low availability outside main production areas. Additionally, German and Polish consumers are concerned about a consistent good quality in carp. Further, carp is seen as a fish which is too big and difficult to prepare (Feucht and Zander, 2018). This corresponds closely to the findings of Richter and Klöckner (2017) according to which seafood produced sustainably is less likely to be preferentially consumed by consumers.

There are two main reasons for being interested in the consumers' image of carp and about their demand for carp: (1) the global protein supply is inadequate and carp production could be an additional protein source and (2) the preservation of historical landscapes, of cultural heritage and of biodiversity connected to carp ponds. Landscapes dominated by carp ponds are a cultural heritage in some areas of central Europe (e.g. Hauber, 2014). 
With this in mind, the aim of this research was to contribute to the discussion on how to increase consumption of carp (products). This research focuses on German and Polish consumers' attitudes towards carp and on their intentions of buying selected innovative carp products. In order to be able to address potential consumers of these new carp products in a well-targeted manner, regression models which explain participants' interest in buying the presented test products were calculated.

This article is structured as follows: following the introduction, materials and methods used in this research are presented and the sample is described. The result section initially presents current carp consumption and the participants associations with carp, continues with consumers' attitudes towards novel carp products, and concludes with a description of the attributes of likely consumers of novel carp products. Conclusions as to the potential of carp products in the markets are drawn in the last section.

\section{Materials and methods}

A quantitative online survey was conducted in Germany and Poland with the aim of identifying consumers' attitudes towards carp and carp products. The questionnaire was divided into several sections: (1) consumption frequency of seafood and of carp, (2) attitudes and associations with carp, (3) opinions on several innovative carp products, (4) psychographic constructs such as subjective knowledge, involvement and domain specific innovativeness and (5) sociodemographic data.

Participants were asked to indicate their associations with regard to carp using a semantic differential scale ranging from one to five and based on 13 bipolar pairs. The ordering of the pairs was randomized in order to avoid any order effect. Next, participants were asked to select three possible barriers to increased carp consumption from a list of 8 statements plus the possibility of making their own suggestions. Afterwards, participants were presented with four carp products which differed between Germany and Poland (see Figure 1). The carp products were chosen in line with preferences found in earlier research based on focus group discussions (Feucht and Zander, 2018).

These products were presented in a randomized order, and the test persons were asked to give their opinions of these products. In total, five items were used to test for attitudes and one item was used to test for purchase intention. The selection of items was based on literature findings. The first item was "I might like the taste" since taste is central for the purchase decision of food (e.g. Brunsø et al., 2009). The next item "Could be healthy for me" refers to the fact that health is a main motive for consuming fish and thus an association with health benefits would support the consumption of the tested products (Brunsø et al., 2009; Jacobs et al., 2015). "I might easily prepare this" represents the convenience factor and indicates the importance of easy preparation, which was found to be particularly relevant in fish consumption (Carlucci et al., 2015). The item "Is something I would like to taste" covers a general interest in a new product which precedes the purchase intention. The intention to purchase is a precondition for the final decision to purchase and is covered by the item, "Is something I would like to purchase." The answers to these statements were measured on a five-point Likert scale ranging from 1 - "I do not agree" to 5 - "I totally agree."

In addition to the attitudes towards carp, subjective knowledge of seafood, involvement with seafood and domain specific innovativeness were elicited from the test persons. Subjective knowledge is the individual self-assessment of the knowledge that a person has about a product category (Altintzoglou et al., 2010), in our case seafood. Earlier research shows that subjective knowledge has a central impact on fish consumption (e.g. Brunsø et al., 2009; Pieniak et al., 2007; 2010). Consumers with a higher level of knowledge eat fish more frequently (Pieniak et al., 2013). The construct was measured with three statements "Compared to an average person I know a lot about seafood," "I have a lot of knowledge about how to evaluate the quality of seafood," "People who know me consider me as an expert in the 
$\mathrm{BFJ}$

122,11

\section{0}

Figure 1.

Carp products shown to the survey participants according to study country

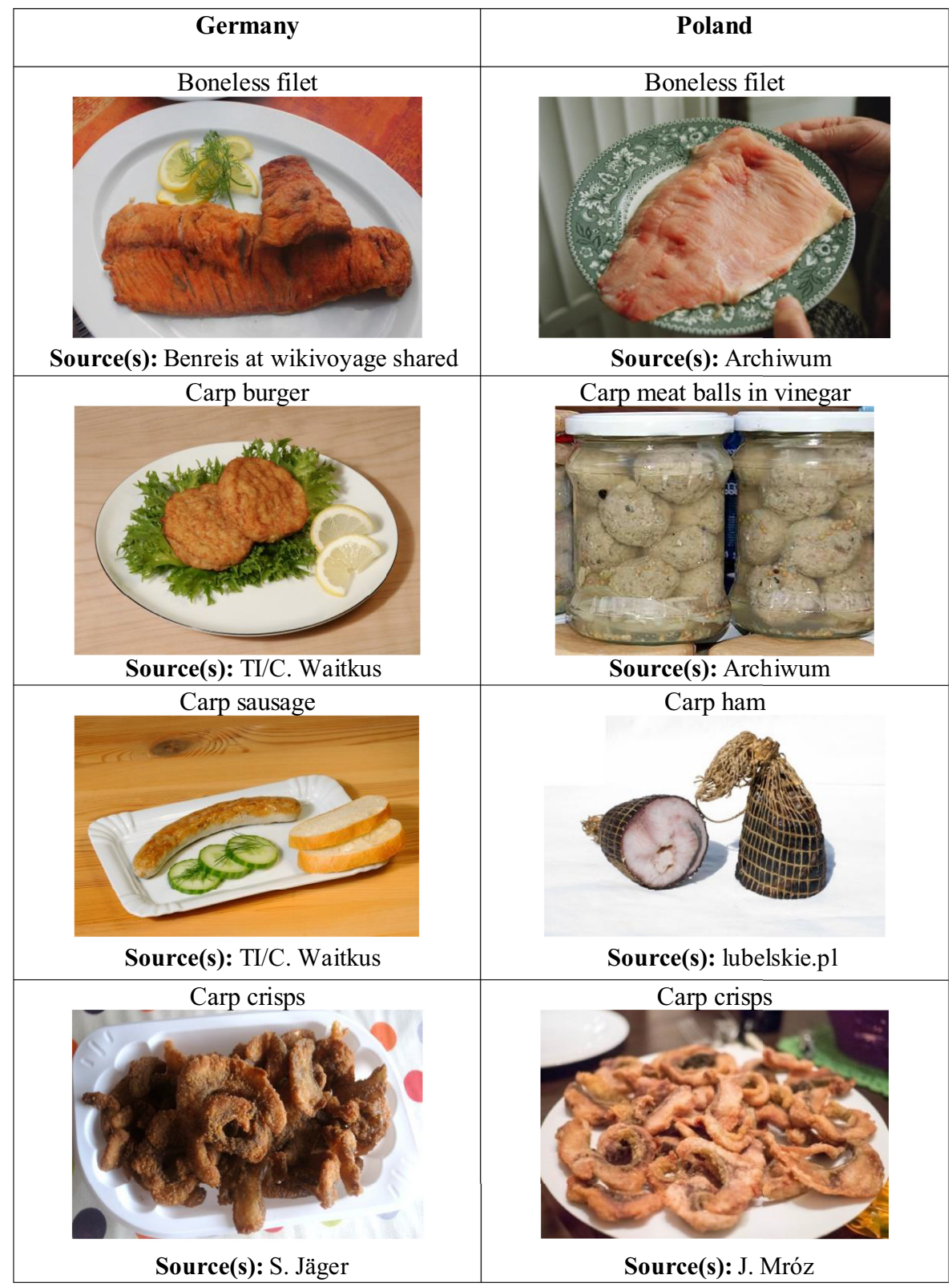

field of seafood knowledge." The items were adapted from the study by Pieniak et al. (2010) and adjusted, where necessary, to the present study context. All statements were measured on a five-point Likert scale ranging from 1 - "I do not agree" to 5 - "I agree."

Food involvement is the extent to which a person attaches concern, care and significance to a particular food product (Olsen, 2001). Involvement has shown to be an important 
determinant for fish consumption, and fish consumption and involvement are positively correlated (Vanhonacker et al., 2011). A study by Olsen (2001) found that consumers' attitudes toward seafood are mediated by seafood involvement. We measured involvement with four statements on a five-point Likert scale, ranging from "do not agree" to "agree": (1) "I am interested in where the seafood I eat comes from," (2) "I enjoy cooking seafood for others and myself," (3) "Making the right choice of seafood is important to me" and (4) "Seafood is an important part of my diet." Statements were adapted from previous studies investigating fish consumption (Bell and Marshall, 2003; Birch and Lawley 2014; Olsen 2001). The chosen statements represent different aspects of involvement. The statements (1) and (3) refer to the product importance, which reflects the growing interest of consumers in purchasing authentic, sustainable and responsibly sourced seafood and are adapted from Birch and Lawley (2014). Statement (2) refers to cooking which represents the hedonic value of preparing fish (Bell and Marshall, 2003; Birch and Lawley, 2014). The statement (4) assesses the enduring importance of seafood products in one's consumption behavior (Olsen, 2001).

When inquiring about consumers' attitudes towards novel products, it is important to consider a consumers' level of willingness to try new products instead of just sticking to the accustomed ones. This willingness to adopt is called consumer innovativeness. Without consumer innovativeness, a newly introduced product stands no chance of becoming established in the market (e.g. Bekoglu et al., 2016; Reinders et al., 2016). Reinders et al. (2016) revealed domain-specific innovativeness as an important predictor of purchase intention for farmed fish. Domain-specific innovativeness measures an individual's innovative behavior with respect to a particular product category - in our case seafood (e.g. Bekoglu et al., 2016). The construct was measured with three statements on a five-point Likert scale ranging from "do not agree" to "agree." The statements were: "In general, I am among the first in my circle to purchase new seafood products." "In general, I would consider buying new seafood products" and "In general, I am among the first in my circle to know the latest seafood product trends." The statements were adapted from Goldsmith and Hofacker (1991) and Reinders et al. (2016).

The survey was conducted with 500 participants in Germany and 499 in Poland. An online panel run by a private market research agency was used for purposive quota sampling. Quotas were set for gender relations (two-thirds women and one-third men) make allowance for the fact that more women than men are still responsible for shopping (e.g. Vanhonacker et al., 2013; Zander and Hamm, 2010). Representativeness was required with regard to age and regional distribution. All participants had to be fish consumers.

In both countries people between the age group of 55 and 70 were those most represented in the sample, whereas the youngest age group (18-24 years) had the lowest share in the study (Table 1). These age distributions are representative for the study countries since they adhere to the quotas set beforehand. People with higher education (sixth form/college, university degree) were overrepresented in our data for both study countries. The dominance of more highly educated people is obvious and may partly be explained by the fact that people with a higher education level tend to eat more fish (Myrland et al., 2000; Hicks et al., 2008).

Most respondents were occasional fish consumers, whereas the share of regular fish consumers was higher in Poland than in Germany. These consumption frequencies are in line with findings by DG Mare (2008), who point out that Polish as well as Germans have a low fish consumption frequency compared to, e.g. consumers in Southern European countries.

The survey was developed in English and German and then translated into Polish by a professional translation service. The content of the survey and the translations were discussed with the Polish research partners. The survey was pretested with 15 participants in Germany. On average, participants spent between 20 and 25 min to complete the survey. 
$\mathrm{BFJ}$

122,11

\begin{tabular}{lcc}
\hline & Germany ${ }^{1}$ & Poland \\
\hline Number of observations & 500 & 499 \\
Age of test persons & & \\
18-24 years & 8.2 & 7.2 \\
25-34 years & 18.4 & 25.7 \\
35-44 years & 23.4 & 20.0 \\
45-54 years & 22.4 & 20.4 \\
55-70 years & 27.6 & 26.7 \\
Gender & & \\
Female & 64.2 & 64.7 \\
Male & 35.8 & 35.3 \\
Education (years of school visit) & & \\
No formal qualification & 0.2 & 0.2 \\
Secondary (GCSE or O'Level) & 50.2 & 22.8 \\
Sixth form/College (A'Level) & 28.2 & 18.6 \\
University degree & 21.4 & 57.5 \\
Fish consumption & & \\
Occasional fish consumers & 61.8 & 55.3 \\
Less than once per month & 14.0 & .0 \\
Once per month & 16.8 & 14.8 \\
Two to three times per month & 31.0 & 32.5 \\
Regular fish consumers & 38.2 & 44.7 \\
About once a week & 29.4 & 33.1 \\
More than once a week & 8.8 & 11.6 \\
\hline
\end{tabular}

Table 1.

Summary statistics of the samples for Germany and Poland

\section{Results and discussion}

\subsection{Carp consumption at present: behavior, associations and barriers}

The survey started with a question on general fish consumption behavior (Figure 2). More than $60 \%$ of the participants consumed fish once a week to two to three times per month. The differences between countries are statistically significant and Polish consumers eat more fish than German consumers $\left(\mathrm{Ch}^{2}\right.$-test).

Figure 2.

Fish consumption frequency by country ( $\%$ of participants)

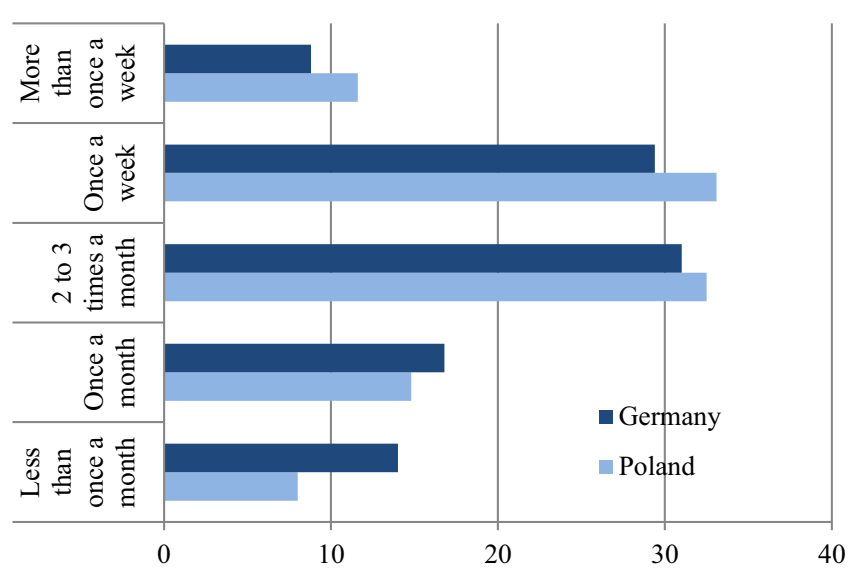


Next, we asked participants in Germany and in Poland about their consumption frequency of carp (Figure 3). The majority of the Polish participants (79\%) indicated that they consume carp once a year or more often, whereas less than half $(38 \%)$ of the German participants revealed a similar consumption frequency. The share of Polish consumers "having tried it once or twice" or "not tried it at all" is much lower than for German consumers.

In both countries, differential semantic profiles for carp were elaborated based on test persons' answers. Carp was perceived to be a traditional fish for special occasions, i.e. Christmas and New Year's Eve (Figure 4). These findings are well in line with results of EUMOFA (2015) who found that carp was mostly consumed during festive seasons (Christian and Jewish) particularly in Eastern and Central Europe. Carp was associated with many bones, even more in Poland than in Germany. Interestingly, bad taste or bad image were not major issues with carp. Likewise, inconvenient portion sizes were not a major concern for a large share of the participants. Regarding the other associations, on average, participants were mainly indecisive in both countries. These results contradict Feucht and Zander (2018), where the overall conception seemed to be more negative when elicited by focus group discussions, to a certain degree. In both countries, consumers were not aware of the eco-friendliness of carp farming. This stresses the limited knowledge of many consumers about fish production and sustainability issues as reported in Feucht and Zander (2018).

Asked about the main barriers to increased carp consumption, participants in both countries stated "too many bones" as an important issue (Figure 5). In Germany, participants believed insufficient knowledge about carp as being an equally important barrier. For Polish participants "moldy taste" presented the second most frequently mentioned barrier, whereas it ranked third in Germany. Polish participants indicated "low availability" of carp as the third most important barrier. The fourth most indicated barrier was "hard to prepare" in Poland and "portion size too big for one person" in Germany. The perception of carp as a "fish from old-fashioned cooking traditions" was indicated similarly frequently as a barrier by German and Polish consumers. Likewise, "hard to prepare" and "health reasons" were equally often mentioned in both countries. The association of carp with inconvenient portion sizes is well in line with earlier research from Vallod (1995), who found that French consumers perceived carp as being too big.

The survey results reveal an age divide in Poland with regard to the perception of carp as a fish that is hard to prepare. Polish participants between 18 and 34 years of age described carp significantly more often as hard to prepare than older participants. In Germany, the perception of carp as a fish which is hard to prepare was equally distributed across the age groups.

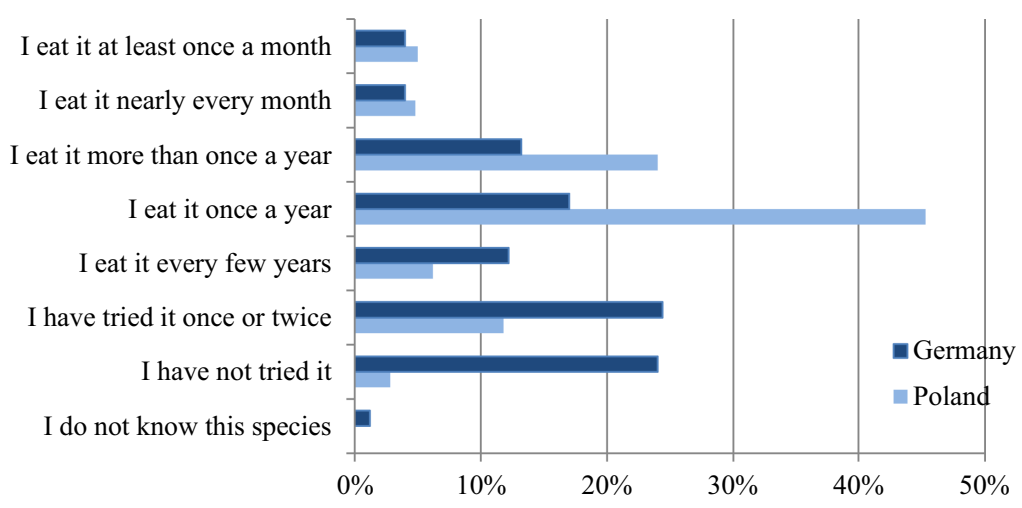

Figure 3. Consumption frequency of carp by country ( $\%$ of participants)

How to increase demand for carp?

3273 
BFJ

122,11

\section{4}

Figure 4 .

Differential semantic profile for associations with carp in Germany and in Poland

Figure 5.

Main barriers for carp consumption in Germany and Poland (\% of participants)
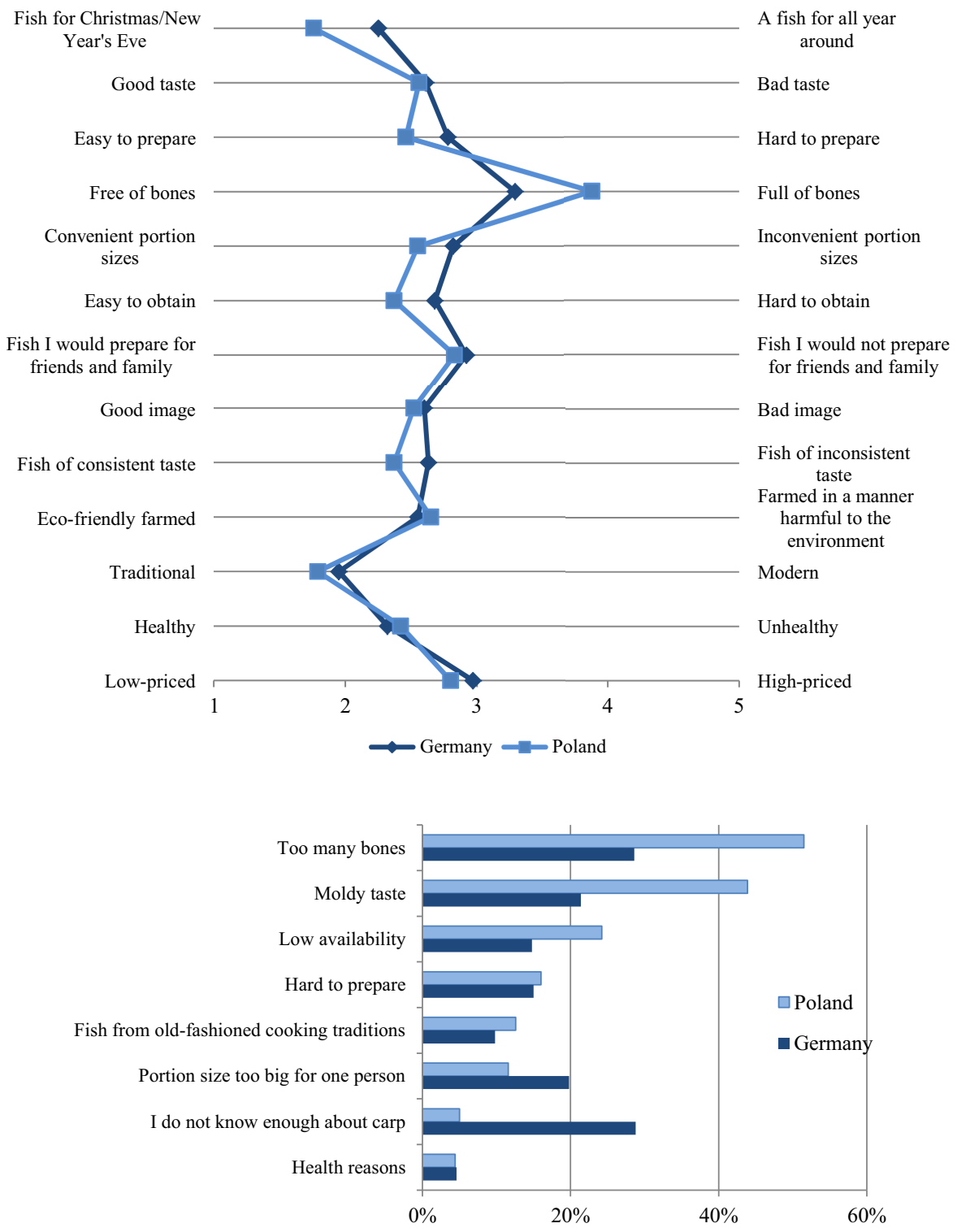

\subsection{Consumers' attitudes towards novel carp products}

One important aim of the underlying research was to identify ways to increase consumer demand for new carp products. In order to achieve this aim, consumers were asked for their attitudes towards novel carp products in both research steps. In the two countries different carp products were selected (see Section 2). All test products require less preparation knowledge than whole carp and are offered in package sizes which fit well into contemporary cooking habits since the shares of precooked and convenience fish on the German seafood 
market are increasing (FIZ, 2018). The growing relevance of convenience food is a global phenomenon and a consequence of changing lifestyles (Kearney 2010; EC, 2016; DG Mare 2008). In the following, we will first look at German participants' reception of the presented novel carp products and afterwards analyze the views of the Polish participants.

In most cases, the presented carp products were unknown to the participants since they either are not available on the national food markets or have very low market shares. In Germany, the bonecut ("boneless") filet performed best followed by the carp burger and carp sausage (Figure 6). Carp crisps were the least appreciated by the participants. In the case of the bonecut filet and the carp burger, half or respectively more than half of the participants could imagine liking the taste of the products, being willing to taste and even purchasing them. The bonecut filet, the carp burger and the carp sausage were perceived by the majority of the German participants as possibly being easy to prepare. In the case of the bonecut filet the positive perceptions accompanied the highest familiarity and the highest perception as possibly being healthy. Carp crisps were the least familiar to the participants and were the least perceived as being healthy and attracted the least interest.

Polish consumers perceived the bonecut ("boneless") filet the most positively (Figure 7). But in contrast to the German participants, Polish participants held the second most positive view about carp crisps with respect to the possibility that they might purchase the product, would like to taste it, that they might find it easy to prepare, and that they might like the taste. Following the bonecut filet and the carp crisps, carp ham was the most positively received product. Carp meat balls in vinegar were the least appreciated by the Polish participants.

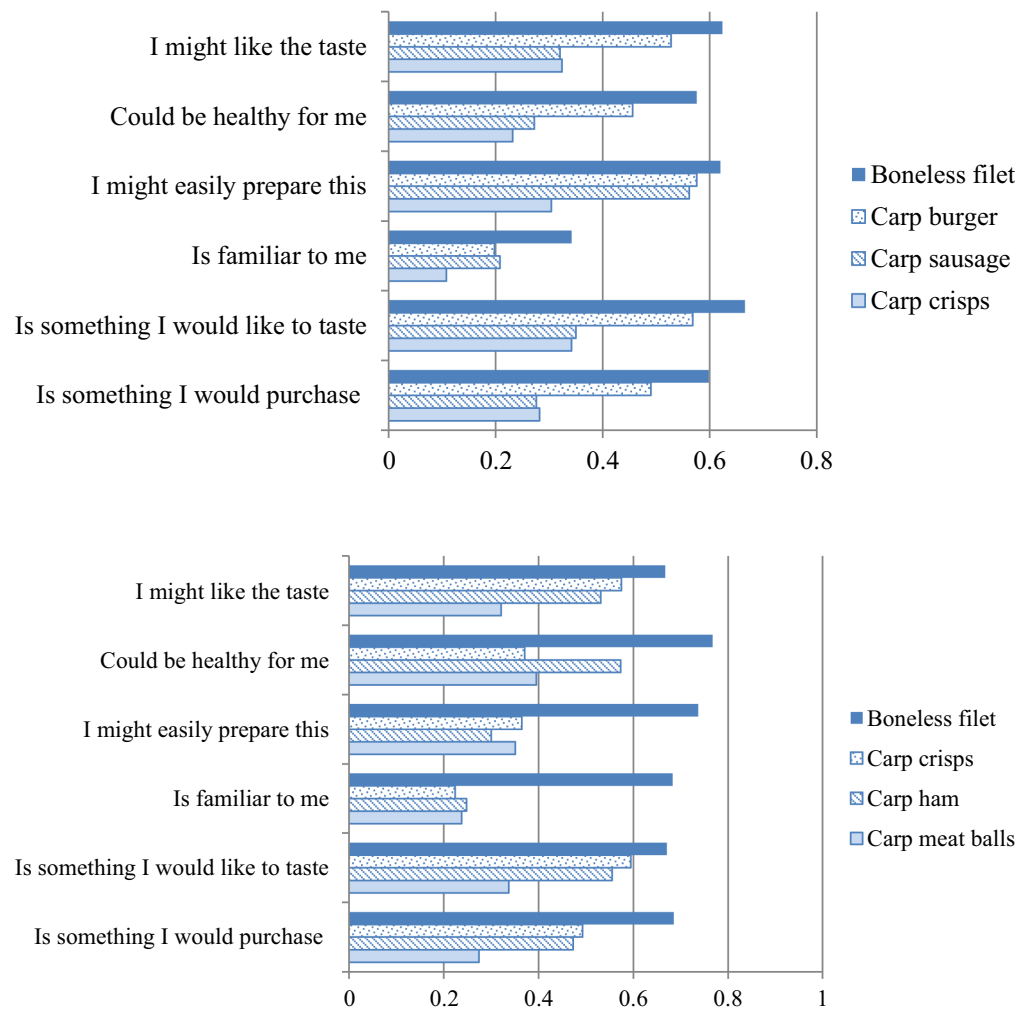

Figure 6. Attitudes towards different carp products in Germany ( $\%$ of participants agreeing with the statements; $N=500$ ) five-point Likert scale

Figure 7.

Attitudes towards different carp products

in Poland $(\%$ of participants agreeing with the statements; $N=499$ ) 
BFJ 122,11

3276

Table 2.

Psychographic scales and their reliability: subjective knowledge, involvement and product-specific innovativeness (Cronbach's alpha)
The bonecut filet, the carp crisps, and the carp ham were the products which nearly half or more than half of the participants could imagine purchasing, would like to taste and might like the taste of it. More than half of the Polish participants perceived the bonecut filet and the carp ham as possibly being healthy. Polish participants were by far the most familiar with the bonecut carp filet.

These results are well in line with the focus group findings of Feucht and Zander (2018). According to Eurobarometer (2017) only $42 \%$ of the German participants were willing to taste new products; the numbers found in this research for interest in new carp products with about $60 \%$ are much higher for Germany. The reason might be that in the present research, specific examples of novel products were presented, allowing for a less hypothetical judgment.

\subsection{Who are the consumers of novel carp products?}

When intending to increase consumption of new products, it is important to identify the potential target groups for these products. It is hypothesized that different innovative products will address different consumer segments. Therefore, in each country, four regression models were calculated, one for each new product. The dependent variable was the purchase intention measured by the item "Is something I would like to purchase" for each of the four test products. Explanatory variables were sociodemographic indicators, such as age, gender, education, household income, and the product-specific attitudes. In addition, the psychographic constructs subjective knowledge, involvement and domain-specific innovativeness were included in the models. All constructs turned out to be highly reliable (Table 2).

3.3.1 The case of German consumers. The results of the regression modelling confirm the hypothesis that the variables impacting the interest in purchasing differ by product (Table 3 ). However, there are also some common results, and the sociodemographic gender variable has a significant impact on almost all products; men tend to be more interested in testing novel products; this is particularly the case for carp sausage. Age has no effect on the interest in buying any new carp products in Germany. Education is negatively correlated with the intention to buy carp filet, carp burgers and carp crisps, this emphasizes that people with lower education are more interested in buying these three products. They found that the impact of gender on the willingness to try novel products fits well with a study by Nordin et al. (2004), which highlighted that food aversion and rejection are more common in women than in men.

For most of the products, the intention to purchase is not dependent on carp consumption frequency. Only for carp filet and carp crisps does consumption frequency have an influence. The perception of carp as a traditional or modern fish positively affects only the purchase intention of carp sausage. The association with carp regarding taste has a significant negative effect for carp filet, carp burgers and carp crisps. This means the higher the perception that carp has a bad taste, the lower the intention to purchase. No effect could be found for sausages. A reason for this might be that for highly processed foods, like sausages, the taste of the main ingredient is usually less relevant. With a better image people's intention to purchase increased only for burgers. Health aspects had no impact for any of the products.

\begin{tabular}{lcc}
\hline Variable & Germany & Poland \\
\hline Subjective knowledge & 0.892 & 0.893 \\
Involvement & 0.838 & 0.781 \\
Domain-specific innovativeness & 0.788 & 0.831 \\
\hline
\end{tabular}




\begin{tabular}{|c|c|c|c|c|c|c|c|c|c|}
\hline \multirow{2}{*}{$\frac{\text { Variable }}{\text { Constant term }}$} & \multicolumn{2}{|c|}{ Filet } & \multicolumn{2}{|c|}{ Burger } & \multicolumn{2}{|c|}{ Sausage } & \multicolumn{2}{|c|}{ Crisps } & \multirow{2}{*}{$\begin{array}{r}\text { How to } \\
\text { increase } \\
\text { demand for }\end{array}$} \\
\hline & 3.015 & \multirow[t]{2}{*}{$* * *$} & 2,548 & $* * *$ & 1.533 & $* * *$ & 1.995 & $* * *$ & \\
\hline Age in years & -0.002 & & -0.004 & & -0.005 & & -0.005 & & \multirow{4}{*}{ carp? } \\
\hline ender (1-male) & 0.149 & \multirow[t]{2}{*}{$*$} & 0.195 & * & 0.381 & \multirow[t]{2}{*}{$* * *$} & 0.163 & & \\
\hline ducation & -0.430 & & -0.662 & ** & 0.278 & & -0.592 & $*$ & \\
\hline Id ne & 0.002 & & -0.031 & & -0.068 & \multirow[t]{2}{*}{$* * *$} & -0.032 & $*$ & \\
\hline quency & 0.053 & & 0.039 & & 0.066 & & 0.062 & & \multirow[t]{2}{*}{3277} \\
\hline & 0.058 & * & 0.023 & & 0.042 & \multirow{3}{*}{ **** } & 0.073 & \multirow[t]{2}{*}{ ** } & \\
\hline & -0.069 & & 0.061 & & 0.172 & & 0.063 & & \multirow{8}{*}{$\begin{array}{r}\text { Table } 3 . \\
\text { Factors influencing the } \\
\text { intention to purchase } \\
\text { different novel carp }\end{array}$} \\
\hline Good & -0.275 & \multirow[t]{2}{*}{$* * *$} & -0.113 & $*$ & -0.065 & & -0.195 & \multirow[t]{2}{*}{$* * *$} & \\
\hline U & -0.063 & & -0.038 & & -0.097 & \multirow[b]{3}{*}{ **** } & -0.099 & & \\
\hline age & -0.027 & \multirow{2}{*}{$* *$} & -0.149 & *** & 0.038 & & 0.054 & \multirow{5}{*}{ **** } & \\
\hline Subjec & -0.175 & & -0.264 & $* * *$ & -0.204 & & -0.042 & & \\
\hline Domain-specific innova & 0.245 & $* * *$ & 0.524 & $* * *$ & 0.378 & \multirow[t]{3}{*}{$* * *$} & 0.472 & & \\
\hline Involvement & 0.275 & $* * *$ & 0.210 & $* * *$ & 0.105 & & -0.011 & & \\
\hline$R^{2}$ & 0.509 & & 0.454 & & 0.353 & & 0.414 & & \\
\hline \multicolumn{10}{|c|}{$\begin{array}{l}\text { Note(s): Dependent variable: "Product XY - is something I would purchase," } 1 \text { - I do not agree at all, } 5 \text { - I products in Germany } \\
\text { fully agree }\end{array}$} \\
\hline
\end{tabular}

Subjective knowledge has a negative effect on test persons' intention to purchase all test products, except crisps. This indicates that consumers with less knowledge about carp are more interested in purchasing the novel products. On contrary, domain-specific innovativeness positively impacts the intention to purchase. Higher involvement in seafood increases the intention to purchase of carp filet and carp burger.

When thinking about marketing and addressing consumers in a well-targeted manner, it is worthwhile to develop consumer profiles for each of the novel products. A first attempt is presented in the following. One common feature exists for all possible novel carp products is high domain-specific innovativeness.

Filet and burger consumers have a rather similar profile: they have a somewhat lower education, they perceive carp to be tasty, and they are highly involved in seafood. And they are more often male. Probable buyers of burgers are younger than filet buyers and have a better image of carp. Carp sausage seems to be a typical product for male consumers with a lower household income, who perceive carp to be a modern product, have a low subjective knowledge, and a high domain-specific innovativeness. Carp crisps buyers really like carp, and they consume carp more frequently, are less formally educated and have a lower income.

3.3.2 The case of polish consumers. For Polish consumers the influence of age is greater and older people tend to be more interested in buying novel carp products (Table 4). Gender has no impact on their intention to buy any of the test products. The interest in buying carp ham or carp crisps increases with the level of education. Income does not have any impact on purchase interest. Fish consumption frequency increases the intention to buy carp crisps, and carp consumption frequency generates the most interest in filet followed by crisps and ham. A positive taste perception of carp promotes the intention to buy all novel carp products. Also, the perception of carp being healthy and having a good image increases the intention to buy most of the new carp products. As in Germany, domain-specific innovativeness increases the intention to purchase all of the test products. Subjective knowledge of seafood does not have any impact on the intention to buy any of the new carp products.

As in the case in Germany, a description of the typical consumer is developed for each of the test products in Poland. All potential buyers are somehow curious and show a high level of innovativeness regarding seafood. The likely buyer of carp filet is slightly older than average, he/she likes the taste of carp, eats carp more frequently, and associates carp with a 


\begin{tabular}{|c|c|c|c|c|c|c|c|c|c|}
\hline \multirow{2}{*}{$\begin{array}{l}\text { BFJ } \\
122,11\end{array}$} & \multirow{2}{*}{$\frac{\text { Variable }}{\text { Constant term }}$} & \multicolumn{2}{|c|}{ Filet } & \multicolumn{2}{|c|}{ Meat balls } & \multicolumn{2}{|c|}{ Ham } & \multicolumn{2}{|c|}{ Crisps } \\
\hline & & 3.005 & $* * *$ & 0.198 & & 0.849 & $* *$ & 1.859 & $* * *$ \\
\hline \multirow[b]{5}{*}{3278} & Age in years & 0.006 & $*$ & 0.020 & $* * *$ & 0.019 & $* * *$ & 0.006 & $*$ \\
\hline & Gender (1-male) & -0.035 & & 0.120 & & 0.020 & & 0.047 & \\
\hline & Education & 0.102 & & 0.048 & & 0.064 & * & 0.074 & $* *$ \\
\hline & Household net income & -0.006 & & -0.014 & & -0.006 & & -0.005 & \\
\hline & Consumption frequency fish & -0.015 & & 0.033 & & 0.039 & & 0.109 & ** \\
\hline \multirow{9}{*}{$\begin{array}{l}\text { Table } 4 \text {. } \\
\text { Factors influencing the } \\
\text { intention to purchase } \\
\text { different new carp }\end{array}$} & Carp consumption frequency & 0.140 & $* * *$ & 0.072 & & 0.077 & * & 0.082 & * \\
\hline & Traditional-Modern & 0.012 & & 0.074 & & 0.060 & & 0.040 & \\
\hline & Good taste-Bad taste & -0.242 & $* * *$ & -0.143 & ** & -0.102 & $*$ & -0.043 & **** \\
\hline & Healthy-Unhealthy & 0.062 & & -0.033 & & -0.042 & ** & -0.157 & $* *$ \\
\hline & Good image-bad image & -0.157 & **** & -0.049 & & -0.078 & * & -0.109 & * \\
\hline & Knowledge & 0.019 & & 0.011 & & -0.002 & & -0.002 & \\
\hline & Domain-specific innovativeness & 0.232 & $* * *$ & 0.494 & $* * *$ & 0.385 & $* * *$ & 0.441 & *** \\
\hline & Involvement & 0.065 & & 0.095 & & 0.181 & ** & -0.018 & \\
\hline & $R^{2}$ & 0.575 & & 0.515 & & 0.529 & & 0.464 & \\
\hline
\end{tabular}
products in Poland (linear regression)

Note(s): Dependent variable: "Product XY - is something I would purchase," 1 - I do not agree at all, 5 - I fully agree

good image, so it can be said that he/she is a carp lover. Potential buyers of carp meat balls are difficult to characterize with these data, only that they are older and like the taste of carp in general. Likely buyers of carp ham are also older, have an above average education and carp consumption frequency. They perceive carp to be tasty, healthy and to have a good image. In addition, they are the only group with a higher involvement regarding seafood. People interested in buying carp crisps have a higher education, they have an above average fish and carp consumption, and they also appreciate the taste and the healthiness of carp as well as the image of carp.

\section{Conclusions}

The present survey results confirm that there is a potential for novel carp products on both markets, this concurrently highlights consumption differences between the two countries. These differences have to be considered when designing strategies to increase carp consumption. In general, German consumers are more reluctant about eating carp than Polish consumers. One reason for this might be the lower familiarity with carp, as indicated by the comparatively lower consumption frequency and the stated lack of knowledge about carp. For the time being, the markets for carp are small in both countries. The most common way of marketing carp is still as whole fish. The results at hand demonstrate that convenience issues - like an abundance of fish bones, difficulties in preparation, excessively large portion sizes, low availability outside of festive seasons, and the risk of moldy taste - hinder a more frequent consumption of carp.

Processed carp products that consider consumers' demand for convenience, no fish bones and small portion sizes can be a solution when aiming at increasing carp consumption (see also Vallod, 1995). This is underlined by the case of Austria, where the economic importance of marketing carp as trimmed fillet has grown (Bauer und Schlott, 2009). Also Guerrero et al. (2009) found that increasing the product variety can promote the consumption of a traditional food such as carp.

Particularly, the bonecut ("boneless") filet is attractive in this respect. In Germany as well as in Poland consumers were interested in the bonecut filet and could imagine purchasing it. Thus, increasing the number of product offerings with bonecut filets and promoting it 
adequately is advisable. The other tested carp products provide further options for market differentiation. In Germany, particularly carp burger and sausage show some potential. Carp crisps and carp ham might be a promising addition to trimmed filet in Poland. In order to open up new market options with all carp products, it is important that off-flavors (moldy taste) are consistently avoided since they present a serious barrier to carp consumption (see also Varble and Secchi, 2013). In order to address potential consumers of the novel carp products in a targeted manner, the found consumer attributes related to the respective products provide some indication. In almost all cases higher product-specific innovativeness increases the intention to by new carp products. In Germany, burgers might attract younger consumers and sausages male people, maybe particularly in barbecue settings. With sausages the perception of carp taste as being good or bad does not have any impact, this indicates that there might be only minor general rejection of carp sausages. In Poland, carp filets address elder people who do like carp, who already eat carp more frequently but who are looking for more convenience. Interestingly, crisps are more appreciated by people with higher education, who like the carp taste and who perceive carp to be healthy. In any case, novel carp products have to be available year round in order to tackle the barrier of low availability. Dependent on the specific product, seasonal requirements should be taken into account (e.g. products for barbecue). Both approaches might also help to cut the predominant association with the (winter) holiday seasons (see also Bätzing, 2014).

In order to let people know about the new products and at the same time to combat the sometimes existent bad image of carp, product tastings, also in combination with information regarding local origin, should be offered at the point of sale. Product tastings have been demonstrated to be a very effective marketing tool to support consumers' interest in novel products and in increasing sales (Heilman et al. 2011). Highlighting local origin caters to the persistent preferences of some consumers for locally produced food and thus can support demand for carp products (e.g. Feldmann and Hamm, 2015). The information provided should include explanations on the possible meal options and on how to prepare these products, considering that difficulties in cooking carp are one of the barriers for its consumption. Additionally, the offered recipes should consider modern cooking trends, such as bowl food, in order to support the disentanglement of carp from the notion of being an old-fashioned fish, showing that carp fits into the modern kitchen regarding convenience and meal options.

This research obtained preliminary ideas on consumer perceptions of carp and selected carp products. The success of novel carp products will ultimately depend on the specific product quality, on its presentation, and on communication with consumers. Future research should test various forms of presentation and communication also using product tastings in order to create products which are highly attractive to consumers.

\section{References}

Altintzoglou, T., Verbeke, W., Vanhonacker, F. and Luten, F.J. (2010), "The image of fish from aquaculture among Europeans: impact of exposure to balanced information”, Journal of Aquatic Food Product Technology, Vol. 19, pp. 103-119.

Bauer, C. and Schlott, G. (2009), "Fillet yield and fat content in common carp (Cyprinus carpio) produced in three Austrian carp farms with different culture methodologies", Journal of Applied Ichthyology, Vol. 25, pp. 591-594.

Bekoglu, F.B., Ergen, A. and Inci, B. (2016), "The impact of attitude, consumer innovativeness and interpersonal influence on functional food consumption”, International Business Research, Vol. 9, pp. 79-87.

Bell, R. and Marshall, D.W. (2003), "The construct of food involvement in behavioral research: scale development and validation", Appetite, Vol. 40 No. 3, pp. 235-244. 
BFJ 122,11

Bergleiter, S. and Meisch, S. (2015), "Certification standards for aquaculture products: bringing together the values of producers and consumers in globalised organic food markets", Journal of Agricultural and Environmental Ethics, Vol. 28, pp. 553-569.

Birch, D. and Lawley, M.A. (2014), "The influence of food involvement on fish consumption", Proceedings of the 2014 Academy of Marketing Conference, 7 - 10 July, 2014, Bournemouth.

Brunsø, K., Verbeke, W. and OlsenandJeppesen, S.O.L.F. (2009), "Motives, barriers and quality evaluation in fish consumption situations. Exploring and comparing heavy and light users in Spain and Belgium”, British Food Journal, Vol. 111, pp. 699-716.

Carlucci, D., Nocella, G., De Devitis, B., Viscecchia, R. and BimboandNardone, F.G. (2015), "Consumer purchasing behaviour towards fish and seafood products. Patterns and insights from a sample of international studies", Appetite, Vol. 84, pp. 212-227.

Clark, M. and Tilman, D. (2017), "Comparative analysis of environmental impacts of agricultural production systems, agricultural input efficiency, and food choice", Environmental Research Letters, Vol. 12 No. 6, doi: 10.1088/1748-9326/aa6cd5/meta.

EC (European Commission) (2016), The Competitive Position of the European Food and Drink Industry, Final Report, Brussels, available at: https://ec.europa.eu/growth/content/study-competitiveposition-european-food-and-drink-industry-0_en.

FAO (2018), "The state of the world fisheries and aquaculture", Food and Agriculture Organisation, Rome, available at: http://www.fao.org/fishery/sofia/en.

FAO/NACA (2010), "Farming the waters for people and food", in Subasinghe, R.P., Arthur, J.R., Bartley, D.M., De Silva, S.S., Halwart, M., Hishamunda, N., Mohan, C. and Sorgeloos, V.P. (Eds), Global Conference on Aquaculture. Food and Agriculture Organisation, Rome and Bangkok.

Feldmann, C. and Hamm, U. (2015), “Consumers' perceptions and preferences for local food: a review”, Food Quality and Preference, Vol. 40, pp. 152-164.

Feucht, Y. and Zander, K. (2018), "Report on the potential of selected innovative products in European markets", Deliverable 2.4: SUCCESS-Project, Braunschweig: Thuenen-Institute.

Feucht, Y. and Zander, K. (2015), "Of earth ponds, flow-through and closed recirculation systems German consumers' understanding of sustainable aquaculture and its communication", Aquaculture, Vol. 438, pp. 151-158.

FIZ (2018), Fischwirtschaft 2018 Daten und Fakten, Fischinformationszentrum, Hamburg.

Goldsmith, R.E. and Hofacker, C.F. (1991), "Measuring consumer innovativeness", Journal of the Academy of Marketing Science, Vol. 19 No. 3, pp. 209-221.

Guerrero, L., Guardia, M.D., Xicola, J., Verbeke, W., Vanhonacker, F., Zakowska-Biemans, S., Mankowski, M., Sulmont-Rosse, C., Issanchou, S., Contel, M., Scalvedi, M.L., Granli, B.S. and Hersleth, M. (2009), "Consumer-driven definition of traditional food products and innovation in traditional foods: a qualitative cross-cultural study", Appetite, Vol. 52, pp. 345-354.

Hauber, M. (2014), "Karpfen: eine alte Tradition neu erleben!", NaturlandNachrichten, Vol. 6, pp. 51-52.

Heilman, C., Lakishyk, K. and Radas, S. (2011), "An empirical investigation of in-store sampling promotions”, British Food Journal, Vol. 113, pp. 1252-1266.

Hicks, D., Pivarnik, L. and McDermott, R. (2008), "Consumer perceptions about seafood - an Internet survey", Journal of Foodservice, Vol. 19, pp. 213-226.

Jacobs, M., Ferrario, J. and Byrne, C. (2002), "Investigation of polychlorinated dibenzo-p-dioxins, and selected coplanar biphenyls in Scottish farmed Atlantic salmon (Salmo salar)", Chemosphere, Vol. 47, pp. 183-191, 2002.

Jacobs, S., Sioen, I., Pieniak, Z., De Henauw, S., Maulvault, A.L., Reuver, M., Fait, G., Cano-Sancho, G. and Verbeke, W. (2015), "Consumers' health risk-benefit perception of seafood and attitude toward the marine environment: insights from five European countries", Environmental Research, Vol. 143, pp. 11-19. 
Karlshoven, K.F. and Meijboom, L.B. (2013), "Sustainability at the crossroads of fish consumption and production. Ethical dilemmas of fish buyers of retail organisations in The Netherlands", Journal of Agriculture and Environmental Ethics, Vol. 26, pp. 101-117.

Kearney, J. (2010), "Food consumption trends and drivers", Philosophical Transactions of the Royal Society B, Vol. 365, pp. 2793-2807, doi: 10.1098/rstb.2010.0149.

How to
increase
demand for
carp?

3281 - etude 1 dans le cadre du contrat cadre Lot 3 - etudes relatives à la mise en oeuvre du FEP' - rapport final", Directorate General for Maritime Affairs, available at: http://ec.europa. eu/fisheries/documentation/studies/study_market/fap_exec_summary_en.pdf (accessed 22 January 2013).

Mergili, S. (2009), "Der Karpfen - prädestiniert für die Öko-Aquakultur, [Carp - perfect for organic aquaculture]", Ökologie\&Landbau, Vol. 151 No. 3, p. 24.

Myrland, O., Trondsen, T., Johnston, R.S. and Lund, E. (2000), "Determinants of seafood consumption in Norway: lifestyle, revealed preferences, and barriers to consumption”, Food Policy and Preference, Vol. 11, pp. 169-188.

Nordin, S., Broman, D.A., Garvill, J. and Nyroos, M. (2004), "Gender differences in factors affecting rejection of food in healthy young Swedish adults", Appetite, Vol. 43, pp. 295-301.

Olesen, I., Myhr, A.I. and Rosendal, G.K. (2011), "Sustainable aquaculture: are we getting there? Ethical perspectives on salmon farming", Journal of Agricultural and Environmental Ethics, Vol. 24, pp. 381-408.

Olesen, I., Alfnes, F., Rora, M.B. and Kolstad, K. (2010), "Eliciting consumers' willingness to pay for organic and welfare-labelled salmon in a non-hypothetical choice experiment", Livestock Science, Vol. 127, pp. 218-226.

Olsen, S.O. (2001), "Consumer involvement in seafood as family meals in Norway: an application of the expectancy-value approach", Appetite, Vol. 36, pp. 173-186.

Pieniak, Z., Verbeke, W., Scholderer, J., Brunsø, K. and Olsen, S.O. (2007), "European consumers' use of and trust in information sources about fish", Food Quality and Preference, Vol. 18, pp. 1050-1063.

Pieniak, Z., Verbeke, W., Olsen, S.O., Hansen, B.K. and Brunsø, K. (2010), "Health-related attitudes as a basis for segmenting European fish consumers”, Food Policy, Vol. 35, pp. 448-455.

Pieniak, Z., Vanhonacker, F. and Verbeke, W. (2013), "Consumer knowledge and use of information about fish and aquaculture", Food Policy, Vol. 40, pp. 25-30.

Reinders, M.J., Banovic, M., Guerrero, L. and Krystallis, A. (2016), "Consumer perspectives of farmed fish”, British Food Journal, Vol. 118 No. 10, pp. 2581-2597.

Richter, I. and Klöckner, C. (2017), "The psychology of sustainable seafood consumption: a comprehensive approach", Foods, Vol. 6 No. 86, pp. 1-14.

Risius, A., Janssen, M. and Hamm, U. (2017), "Consumer preferences for sustainable aquaculture products: evidence from in-depth interviews, think aloud protocols and choice experiments", Appetite, Vol. 113, pp. 246-254.

Teufel, J., Stamer, A. and Bergleiter, S. (2004), "Ökologische fișchproduktion: struktur, entwicklung, probleme, politischer handlungsbedarf", Final report BÖLN 02OE314, Freiburg. available at: http://orgprints.org/4200.

Vallod, D. (1995), "Carp processing and market analysis: a case study in France”, Aquaculture, Vol. 129 No. 4, pp. 476-477.

Vanhonacker, F., Altintzoglou, T., Luten, J. and Verbeke, W. (2011), "Does fish origin matter to European consumers? Insights from a consumer survey in Belgium, Norway and Spain", British Food Journal, Vol. 113, pp. 535-549.

Vanhonacker, F., Pieniak, Z. and Verbeke, W. (2013), "European consumer pceptions and barriers for fresh, frozen, preserved and ready-meal fish products", British Food Journal, Vol. 115 No. 4, pp. 508-525. 
BFJ

122,11

3282
Varble, S. and Secchi, S. (2013), "Human consumption as an invasive species management strategy: a preliminary assessment of the marketing potential of invasive Asian carp in the US", Appetite, Vol. 65, pp. 58-67.

Verbeke, W., Vanhonacker, F., Sioen, I., Van Camp, J. and De Henauw, S. (2007), "Perceived importance of sustainability and ethics related to fish: a consumer behavior perspective", Ambio, Vol. 36, pp. 580-585.

Whitmarsh, D. and Palmieri, M.G. (2011), "Consumer behaviour and environmental preferences: a case study of Scottish salmon aquaculture”, Aquaculture Research, Vol. 42, pp. 142-147.

Zander, K. and Hamm, U. (2010), "Consumer preferences for additional ethical attributes of organic food", Food Quality and Preference, Vol. 21 No. 5, pp. 503-224.

Zander, K. and Feucht, Y. (2018), "Consumers' willingness to pay for sustainable seafood made in Europe", Journal of International Food and Agribusiness Marketing, Vol. 30 No. 3, pp. 251-275.

\section{Corresponding author}

Katrin Zander can be contacted at: k.zander@uni-kassel.de

For instructions on how to order reprints of this article, please visit our website: 